\title{
Cross Border Economic Convergence and EU Integration Process
}

\author{
ŽAN JAN OPLOTNIK, BORUT VOJINOVIĆ \& SANJAY ACHARYA
}

\begin{abstract}
The real benefits of integrating different economic areas and regions into one common economic, monetary, and sometimes also fiscal area are among the most important issues to be resolved because the win-win situation for all participants should prevail unless the Member States or local authorities lose their interest in further participation. In this study, we compare the speed and the real benefits of economic integration between the three groups of Member States that emerged following the last big EU enlargement. The first group is composed of the so-called old EU Member States. The second group represents the countries that achieved full membership in 2004 (the so-called new Member States), and in the third group, there are the countries that are now in the negotiation process for EU membership. We then draw from the experience of these new Member States to derive implications for a possible new round of EU enlargement. The conclusion of this paper is therefore supposed to be some kind of direction for the new candidate countries. The results offer an answer to the question of what degree of convergence the new EU10 Member States reached within certain macroeconomic fundamentals during the period of their accession negotiations
\end{abstract}

KEYWORDS: • economic convergence $・$ EU integration $\bullet$ transition economies $\bullet$ integration $\bullet$ EU accession $\bullet$ economic trends

Correspondence AdDress: Žan Jan Oplotnik, Ph.D., Faculty of Economics and Business, university of Maribor, Razlagova 14, SI-2000 Maribor, Slovenia, email: zan.oplotnik@uni-mb.si. Borut Vojinović, Ph.D., GEA College - Faculty for Entrepreneurship, Dunajska 156, SI-1000 Ljubljana, Slovenia, email: borut.vojinovic@guest.arnes.si. Sanjaya Acharya, Ph.D., Reader in Economics, Saraswati Campus, Tribhuvan University, Thamel 29, Kathmandu, Nepal, email: sanjaya_acharya@hotmail.com. 
The Central and Eastern European countries' prospects of joining the European Union heavily depend on, inter alia, the introduction of structural reforms in the way of acquiring certain institutional attributes, and on economic policies to correlate with a higher degree of convergence with those of the EU. This paper analyses the convergence performance of the old EU Member States, the EU10 new Member States, ${ }^{1}$ and the group of the EU candidate countries. Due to the relative openness and the close economic relations between transition economies in Central and Eastern Europe, economic interactions, or lack thereof, are likely to be revealed by the behaviour of macroeconomic fundamentals. The basic problem of this macro-region is a relatively low level of economic, social and territorial cohesion. All the CEE countries embarked upon an uneasy road of privatising state-owned companies that had to undergo critical restructuring along the way. At the same time, these countries have striven to establish a workable framework for international trade and cooperation to facilitate the transition process. A decrease in the real income of the population will quickly affect the legal economy by shrinking demand, which in turn will result in falling revenue for the retail trade, in small enterprise bankruptcies, in a decrease in GRP (Gross Regional Product), and in a reduction in regional budget revenues. Thus, a question arises as to how successful the countries have been in achieving a certain degree of natural economic integration. One way to answer this question is to perform a test for convergence in macroeconomic fundamentals in the CEE countries. In doing so, we extend the growth convergence methodology to a set of selected macroeconomic fundamentals in order to obtain a broader picture of one aspect of the economic transition. The further a country is in its transition process towards a market economy, the more important the standard neoclassical determinants of economic growth become. If the growth process is described adequately by the neoclassical determinants of growth (along the lines of Ramsey, 1928, Solow, 1956, or Cass, 1965), then some clear forecasts regarding the long-run comovement of macroeconomic aggregates follow.

There are some related studies that complement ours. Henrekson, Thorstensson, and Thorstensson (1997) examine the role of trade and institutional integration in economic growth, using a purely empirical approach in the European Community (EC), and the European Free Trade Area (EFTA) countries along with a sample of OECD countries. In their study using a cross-sectional analysis, they found that joining the EU or EFTA enhances growth. By using a panel regression, CrespoCuaresma, Ritzberger-Grünwald, and Silgoner (2002) examine the impact of European integration on economic growth of the current EU Member States. They find that the length of EU membership has a significant and positive effect on growth, and that it is higher in poor countries, suggesting an asymmetric impact of EU membership. These studies solely focus on a regression analysis of the relation between membership and growth without providing an underlying theoretical framework, or they discuss the importance of real convergence for potential EU 
candidate countries, along with its policy implications for some preliminary estimates of convergence development in these economies. Martin and Velázquez (2001), Wagner and Hlouskova (2002), Boldrin and Canova (2003), Vojinović and Oplotnik $(2008,2010)$ provide a descriptive analysis of how different experience of convergence affected economic growth in the recent EU Member States after joining the EU that employs different growth scenarios. Economic cohesion, as measured by gross domestic product (GDP) per capita verified by purchasing power parity (PPP), is expected to increase in 2010-2020, and that would be the opposite of the tendencies observed in the 1997-2003 period. They examine the beneficial effects of EU membership, and how long it will take the EU candidate countries (now the new EU10 Member States) to fully complete the convergence process. They emphasise the importance of national policies to achieve a sustained period of significant economic growth above the EU average, and hence real convergence towards the EU standards.

\section{Data and a Choice of Groups}

The analysis focuses on the new EU10 Member States. In this context, especially Eastern European countries (including Cyprus and Malta) and hence, excludes other transition economies. It uses monthly data from 29 countries. In the first group there are the representatives of the old EU15 Member States. The new EU10 Member States are in the second group of the analysis sample. In the third group there are some countries that attempt to adopt the neoclassical growth model on their way towards the EU. These two countries are at the moment Albania and Croatia, while Romania and Bulgaria have become full members of the EU.

When choosing countries, we also take into account the data problems in other transition countries such as Russia, Ukraine, and Belarus. Data availability and reliability are often questionable in these countries. Only recently have these countries adopted the IMF standards for data collection and purification. Furthermore, frequent changes in measurement methodology make their data rather inconsistent. The data span is from January 1993 to December 2003. Monthly data on real industrial output, money aggregate (MI), producer and consumer prices, and nominal and real interest rate spreads were compiled from the International Monetary Fund's International Financial Statistics in order to ensure dataset reliability. Statistical Office Bulletins and the bulletins of the national banks of the chosen countries were used to ensure data consistency. We use industrial output as a proxy for the gross domestic product (GDP). This measure allows us to form panels of dimensions comparable to those of other variables that are large enough to yield reliable results obtained by a technique described in the section below. In our analysis, we concentrate on the growth rates of the aforementioned variables. The only exceptions are interest rate spreads that are defined later. Since we use monthly data, and since almost any monthly data are subject to seasonal effects, we calculate seasonally adjusted growth rates. We 
use seasonal differencing, which lowers the variance of such time series. Thus, we define the variable $X t$ as a logarithmic 12th difference of the original data, i.e.,

$$
\mathrm{Xt}=\ln \mathrm{Vt}-\ln \mathrm{Vt}-12
$$

where $V t$ is the original variable at time $t$, and $X t$ is a growth rate of a variable $\mathrm{V} t$ over a period of 12 months, i.e., the January-to-January growth rate. Tables 8 and 9 show the basic statistics, averages, and standard deviations of the growth rates defined above. The annual growth rate calculated monthly tends to smooth out the time series in a way that eliminates the time-dependent fluctuations that arise on both the real and nominal sides of the economy. The seasonal nature of fluctuations may be either economic or administrative. By definition, industrial output as a subset of the GDP consists of several parts, among which there are investment and consumption. The cyclical behaviour of investment in transition economies is well documented, and consumption exhibits a cyclic pattern as well. Correspondingly, for social rather than for economic reasons, most transition countries favour a gradual liberalisation of prices. Deregulation measures are usually announced ahead of time, and they are taken on prescheduled dates. Each year, such administrative measures prompt several price level jumps in both consumer and producer prices. Interest rate spreads are analysed in the form below. The spread is usually defined as a difference between lending and deposit interest rates. In a nominal form, this difference is affected by inflation, and thus the measure would be distorted in periods of higher inflation. Therefore, we define the nominal spread as the ratio of nominal lending to deposit interest rates. As an alternative, we also define the real spread as the difference between nominal lending and deposit interest rates minus inflation, i.e., the difference between real lending and deposit interest rates. Table 9 shows the basic statistics, averages, and standard deviations of these interest rate spreads.

\section{Table 1: Country groups}

\begin{tabular}{cll}
\hline Group & Number & \multicolumn{1}{c}{ List of Countries in a group } \\
\hline I & 15 & $\begin{array}{l}\text { Austria, Belgium, Denmark, Finland, France, Greece, } \\
\text { Ireland, Italy, Luxemburg, Germany, The Netherlands, } \\
\text { Portugal, Spain, Sweden, and UK }\end{array}$ \\
\hline II & 10 & $\begin{array}{l}\text { Cyprus, Czech Republic, Estonia, Lithuania, Latvia, } \\
\text { Hungary, Malta, Poland, Slovakia, and Slovenia }\end{array}$ \\
\hline III & 4 & Albania, Romania, Croatia, and Bulgaria \\
\hline
\end{tabular}

For the purpose of further analysis, the countries are pooled in several logically differentiated groups that allow us to form panel data sets. Due to our aim to employ only reliable and consistent data, certain panels are unbalanced. There is a maximum of 2124 observations in each panel, and the dimension of each panel data structure changes accordingly. Table 1 shows the composition of the various groups for which we test the convergence hypothesis. These groupings are not 
made on an ad hoc basis, but they reflect certain institutional attributes of the transition process as well as its geographical and historical aspects. Given the focus of the paper, we also present the data on the macroeconomic variables for specific groups of countries in graphical form (Figs. 1 to 6). In addition to these variables, the figures also show time series of each group's average in order to illustrate the basis for some of the key statistical results concerning convergence within a particular group. With regard to the rationale for the groupings, an institutional criterion is related to full membership in the EU. So, the second group represents the countries that reached full membership in 2004 (the so-called new EU Member States).

Seen through Western eyes, linking the economies of Central and Eastern Europe to those of the European Union (EU) is generally considered the principal means of securing the future growth prospects and political stability of the former Soviet Bloc countries. The European Union's own strategy of integrating the CEE economies into the Western sphere gave rise to the Europe Agreements and to a gradual process of accession that led to EU membership. While the Europe Agreements included a political component, the principal tools of economic renewal were trade liberalisation protocols and the broad market reform objectives that had to be achieved by the CEE countries to meet the requirements (laid out by the European Commission's White Paper) for EU membership ${ }^{2}$. The EU limited the first round contenders to a subset of five countries (plus Cyprus). The countries that began official membership negotiations in March 1998 were the Czech Republic, Estonia, Hungary, Poland, and Slovenia. As a result of the Helsinki EU summit in December 1999, the rest of the CEE countries (Bulgaria, Latvia, Lithuania, Romania, and Slovakia) and Malta were invited to enter into EU membership negotiations on 14 and 15 February 2000. Negotiations began on 28 March 2000. More recently, it was agreed at the Gothenburg Summit that some CEE countries could potentially become EU members as early as January 2004. From the EU side, 2004 was mentioned as the first possible membership date for individual applicants. This group reflects geographical and historical aspects relevant to transition countries.

We address two other groups: the old EU Member States (15 states) and the group of the new accession countries (Croatia and Albania), i.e., the countries that are in the process of negotiations for EU membership. Figures 1 to 6 illustrate the time path of variables related to all the three groups of countries. Pooling the countries into certain groups is meant to show not only the consistency, but also the sensitivity of our results. A detailed description of the method for convergence testing is given in the next section. It concentrates on investigating country groups to see how differences in various macro variables have evolved over time, i.e., whether differences have increased or decreased. 
Empirical research on economic growth has witnessed an enormous interest during the last 10 to 15 years. One of the reasons for this renewed interest is the current general interest in growth theory. Another reason is the formulation and empirical investigation of different notions of convergence within this framework. Convergence in key economic variables may be researched by several methods. Baumol (1986), Barro (1991), and Barro and Sala-i-Martin (1991, 1992) pioneered the conventional approach that examines cross-sectional relationships between the per capita growth rate over time and its initial level. In their research, Bernard and Durlauf (1995) show that this conventional approach is too simple and that it is applicable only under very strong assumptions. We focus on the new EU10 Member States, thereby deriving lessons from these countries' experience for the candidate countries. In addition, we provide lessons for the candidate economies [in a similar way that Martin and Velázquez (2001), and Boldrin and Canova (2003) do] by focusing on the empirical evidence from the recent EU members.

The following econometric methodology that has been used in several published studies relies on weaker assumptions, and it makes use of a combination of crosssection and time-series data. This approach was used by Ben-David $(1995,1996)$ who performed an analysis of real per capita income growth in numerous countries. Kočenda and Papell (1997) applied this methodology to study inflation convergence in the European Union. Kočenda and Hanousek (1998) used it to test for convergence and integration of Asian capital markets. The recent adoption of panel-data estimation techniques combines the dynamics in time series with crosssectional variation in convergence analyses. An authors group uses panel unit root techniques to check for the existence of a common stochastic trend as evidence of convergence across a panel of countries (e.g., Evans and Karras, 1996; Evans, 1998, Fleissig and Strauss, 2001). The recent applications of this technique (e.g., Kočenda, 2001) assume homogeneity in growth rates across the panel of countries studied. Kutan and Yigit (2004), however, show that Kočenda's evidence for convergence is sensitive to the assumption of homogeneity in growth rates, and that further investigation, especially one allowing for heterogeneity, is necessary. That is why Kutan and Yigit (2004) choose to employ dynamic panel data estimation techniques with the assumption of unobservable country-specific heterogeneity (Islam, 1995; Lee, Pesaran \& Smith, 1997; Nerlove, 2000). Nevertheless, we adopted a well-defined methodology and the calculated convergence coefficients. However, we start our convergence analysis by modelling the time path ${ }^{3}$ of macroeconomic variables for a group of $i$ individual countries with observations spanning $t$ time periods as an autoregressive process, i.e.,

$$
\mathrm{Xi}, \mathrm{t}=\alpha+\Phi \mathrm{Xi}, \mathrm{t}-1+\mathrm{Ci} ; \mathrm{t} ;(2)
$$


where $X t$ is the growth rate of a specific variable over a 12-month period as defined by (1), or an interest rate spread as defined earlier. The fact that the variables are modelled as an autoregressive process is based on a common practice in literature. It does not represent any theory of how this variable is determined. The convergence measure adopted is based on the subsequent relationship that describes the dynamics of the differentials of the respective variables in a panel setting. Formally, we can transcribe this as

$$
X i t-\bar{X} t=\Phi\left(X_{i, t-1}-\bar{X}_{t-1}\right)+u_{i, t}
$$

where $\bar{X}_{t}=\frac{1}{n} \sum_{i=1}^{n} X_{i, t}$.

In the presence of pooling, the intercept $\alpha$ vanishes because, by construction, the differentials have a zero mean over all the countries and time periods.

The convergence in the context above requires that the differentials of the respective variables become smaller and smaller over time. For this to be true, $\Phi$ must be less than 1 and statistically significant. On the other hand, $\Phi$ greater than 1 and statistically significant indicates divergence. Ben-David (1995) has established that a sub-unity convergence coefficient $\Phi$ is indeed a robust indication of convergence, and this is respectively true for divergence when $\Phi>1$. The author has performed 10,000 simulations for each of three possible cases in which data should portray the processes of convergence, divergence, and neutrality. His numerous simulations provide ample evidence of convergence or divergence when these features truly reflect the situation. When neutral data with no strong inclination in either direction are used, the convergence coefficient $\Phi$ tends towards unity. Once calculated, the estimated $\Phi$ provides an indication of the speed of convergence within the given group. From the construction of the test, it follows that, as the value of the statistically significant coefficient $\Phi$ approaches unity, the speed of convergence decreases. In order to make the speed of convergence much more readily interpretable, it is useful to compute its halflife. The half-life of the convergence process is the number of time periods that it takes to cut the gap in half. The half-life is derived and used by Ben-David (1993, $1996)$, and it is given by $\ln (0.5) / \ln (\Phi)$. The recent adoption of panel-data estimation techniques combines the dynamics in time series with cross-sectional variation in convergence analyses.

For a particular group of countries, the convergence coefficient $\Phi$ can be obtained by estimating Eq. (3). In order to remove any possible serial correlation from the data, we rewrite Eq. (3) in the form of the augmented Dickey and Fuller (1979) test, which is 


$$
\boldsymbol{d}_{i, t}=\boldsymbol{\Phi}_{i, t-1}-\sum_{j=1}^{k} \gamma_{j \Delta} \boldsymbol{d}_{i, t-j}+Z_{i, t}
$$

where the differential is $d_{i, t}=X_{i, t}-\bar{X}_{t}$, and its first difference is $\Delta d_{i, t}=d_{i, t}-d_{i, t-1}$. The subscript $\mathrm{i}=1, \ldots \ldots, \mathrm{k}$ indexes the countries in a particular group. The number of lagged differences (k) in Eq. (4) is determined by using the parametric method proposed by Campbell and Perron (1991), Ng and Perron (1995), and Kočenda (2001). An upper bound of the number of lagged differences $\left(k_{\max }=7\right)$ is initially set at the appropriately chosen level. The regression is estimated, and the significance of the coefficient $k$ is determined. If the coefficient is not found to be significant, $k$ is reduced by 1 , and Eq. (4) is reestimated. This procedure is repeated with a diminishing number of lagged differences until the coefficient is found to be significant. If no coefficient is found to be significant in conjunction with the respective $k$, then $k=0$ and a standard form of the Dickey-Fuller test is used in the analysis. A one-percent value of the asymptotic normal distribution is used to assess the significance of each lag. The advantage of this recursive $t$-statistic method over alternative procedures where $k$ is either fixed or selected in order to minimize the Akaike Information Criterion is discussed in detail by $\mathrm{Ng}$ and Perron (1995). The above methodology, i.e., the panel unit-root test, exploits the effect of cross-variances in a pooled time series of moderate length. A theory was derived by Levin and Lin (1992). It shows that the statistical power of a unit-root test for a panel may be of an order of magnitude exceeding the power of the test for a single time series.

Previously applied econometric research has demonstrated specific advantages of utilizing panel data in studying a wide range of economic issues. Generally, the cross-sectional variation that is present in the panel data improves the estimation of underlying parameters. Thus, tests for the significance of such parameters have greater power. Levin and Lin (1992) tabulated critical values that could be used to evaluate the statistical significance of the convergence coefficient $\Phi$. However, in the case of a small sample size, those values do not account for contemporaneous correlation in the residuals that can have a dramatic effect on those critical values. In the light of this, it is essential to compute critical values by using Monte Carlo simulation. The exact finite sample critical values for each group were computed as follows: we generated randomly artificial panel data under the null hypothesis of a unit root. Each artificial data set had the same cross section and time-series dimensions because the actual data and contemporaneous residual correlation matched that of the sample estimates. Then that artificial data set was analysed by using the same unit root test procedure, including lag order selection as applied to the real data. Finally, after repeating the steps for 5000 artificial data sets, the test statistic values were sorted to determine one-percent critical values that allowed verification of the statistical significance of the convergence coefficient $\Phi$. 
Empirical findings induced a major systemic transformation from centrallyplanned to market-based economies. For nearly all the Central and Eastern European countries, membership within the European Union was one, if not the primary goal of policy. However, the prospects of becoming a Member State of the European Union depend strongly on the economic performance of the respective applicant country. As all potential entrants, the Eastern European applicant countries had to meet legal standards, and they had to achieve satisfactory levels of political development. Criteria were laid down at the Copenhagen summit. For all the Eastern European countries, we looked into the rough picture of the last thirteen years. The initial period of transition was characterised by drastic falls in output, high inflation, and rising unemployment (for example, see Kornai, 1994, Fischer, Sahay and Vegh, 1998a, Berg et al., 1999, or Fischer and Sahay, 2000). The most drastic example was real GDP growth of about $-40 \%$ in Latvia in 1992. For most countries in the sample, with the exception of Bulgaria, Romania, and Albania, output started to grow sustainably in 1994 or 1995. Inflation rates also soared. Some countries experienced hyper-inflation. Again, with the exception of Bulgaria, Romania, and Albania, by the end of the 1990s, inflation was brought down to single-digit or to low two-digit figures. Thus, among these countries, the stabilisation policy has been successful, and economic growth is widely experienced now.

For all country groups, the convergence test results are presented in Tables 2 to 7 . Each table is devoted to the results for a particular macroeconomic variable. In order to correctly translate the results from the tables, it needs to be pointed out that through test construction, as the value of the statistically significant coefficient $\Phi$ approaches unity, the convergence rate becomes smaller. In order to interpret the convergence speed more readily, the tables also show the computed half-life (H-L), or the number of time periods that it takes to cut the gap in half. As we interpret the results of the analysis, it has to be mentioned that half-life is relatively high for the first country group (the old EU15 Member States) in Tables 3,4 , and 6 . This is the consequence of including Luxembourg and Ireland into the analysis (time deviations, the salaries there are significantly high, e.g., the two highest GDP per capita levels in 2001, and therefore they could be considered as a diverging force). 


\subsection{Industrial Output}

Table 2 presents the results of the convergence test performed on the real industrial output growth rate. The coefficient $\Phi$ is statistically significant for all groups. Based on the measure of half-life, the new EU10 Member States (group II) show the fastest convergence rate, followed by the first group of the old EU15 Member States. To a substantial extent, the second-group countries have achieved a common objective characterised by a high degree of integration due to the process of achieving the broader objectives of the market reform required for EU membership. The relatively fast convergence of industrial output growth rates should nevertheless be considered by taking the large initial differences into account. In any event, the speed of convergence is not comparable in all three cases. The high speed of convergence for these two groups is in sharp contrast to the low speed of convergence for the third group of countries. The evolution of Romanian, Albanian, Bulgarian and Croatian real output growth was quite different from the other two groups due to the behaviour of producer prices, and thus it caused a substantial slowdown in the speed of convergence between these three groups (see also Figure 1). In any event, these results indicate that a relatively high degree of convergence in real industrial output growth has already been achieved in the third group countries. The CEE countries started the transition process under quite different conditions. In terms of aggregate per capita output, the Czech Republic had lower growth, but it also started at a higher base. This was the opposite case in Poland, and to some extent in Hungary. The Baltic States were still part of the former Soviet Union and dependent on it when transformation was under way in Central Europe. The economic growth in these countries depends on two sets of factors; see, for example, Fischer, Sahay, and Vegh et al. (1998b). On the one hand, economic growth depends on the factors directly associated with the transition process that can further be separated into initial conditions and reform policies. But on the other hand, it depends on the determinants of long-run growth as described by the neoclassical growth theory. DeMelo et al. (1997) have found that initial conditions do matter, and that the adverse effects of unfavourable initial conditions can be overcome by strict commitment to reform policy. It is safe to assume that these conditions influenced the evolution of industrial output during these years.

Table 2: Real industrial output growth rate

\begin{tabular}{cccrccc}
\hline Group & No. & \multicolumn{1}{|}{$\boldsymbol{\Phi}$} & t-stat $(\boldsymbol{\Phi})$ & $\mathbf{k}$ & H-L & Standard error \\
\hline I & 15 & $0.872^{*}$ & -47.99 & 7 & 5.06 & 0.018 \\
II & 10 & $0.818^{*}$ & -36.16 & 7 & 3.45 & 0.023 \\
III & 4 & $0.972^{*}$ & -61.57 & 7 & 24.41 & 0.016 \\
\hline
\end{tabular}

Note: No. stands for the number of countries in a particular group, k denotes the number of lags, and $\mathrm{H}-\mathrm{L}$ stands for half-life. *Significant at $1 \%$ level. 


\subsection{Prices}

Tables 3 and 4 present the convergence test results with regard to the growth rates of producer and consumer prices. The convergence coefficients are statistically significant. The results show that there is the greatest degree of convergence in the growth rates of prices in the second group countries, and that convergence is higher for producer rather than for consumer prices. Figures 2 and 3 also show that the price growth rates converge, and that they are mostly reduced to singledigit inflation (under 10\%) after January 1998 (PPI) and December 1998 (CPI). We attribute this to two facts. Firstly, the new EU10 Member States had relatively comparable starting conditions after the beginning of the contraction phase. Secondly, those states followed a relatively similar stabilisation policy. They achieved the broader objectives of the market reform required for EU membership. After experiencing a period of very high inflation, this policy allowed them to import a lower inflation rate, which they would presumably not have achieved had they behaved autonomously. The H-L results are also very high in both price segments for the first group. Concerning the first group of old EU15 Member States (relatively high H-L, especially in the segment of CPI), prior to the introduction of a single currency within the European Union, economists considered it a necessity that monetary decisions of the member states be synchronised. This gave way to a regulatory framework that ranged from the European Monetary System (EMS) of 1979 (limitation of exchange rate divergence) to the Maastricht Treaty of 1992. Among other convergence criteria, the Maastricht Treaty defined explicit convergence goals for inflation rates. Inflation rates were to stay within certain borders, interdependent of the development in the fellow Member States. From the beginning of the eighties until the euro introduction, inflation rate declined within the euro zone. In recent years, however, a proliferating inflation divergence has been noticeable, and it remains questionable if this divergence is only short-natured, or if inflation rates in the euro zone have been systematically drifting apart after the introduction of the euro. Hence, it is going to implicitly require more time to cut the gap in their inflation rate disparities by half. The third group countries (i.e., the Balkan group of four countries) suffered from a prolonged period of high inflation with a dramatic surge in consumer prices, which occurred in 1996 and lasted well into 1997 (see Fig. 3). Thus, from a purely statistical point of view, it is understandable that the Balkan states were able to cut their inflation differences quite quickly because they started from a very high base. 
Table 3: Producer prices, growth rate

\begin{tabular}{clrlllc}
\hline Group & No. & $\boldsymbol{\Phi}$ & t-stat $(\boldsymbol{\Phi})$ & $\mathbf{k}$ & H-L & Standard error \\
\hline I & 15 & $0.949^{*}$ & -156.88 & 6 & 13.24 & 0.006 \\
II & 10 & $0.908^{*}$ & -72.15 & 6 & 7.18 & 0.012 \\
III & 4 & $0.956^{*}$ & -85.53 & 6 & 15.40 & 0.011 \\
\hline
\end{tabular}

Note: No. stands for the number of countries in a particular group, $\mathrm{k}$ denotes the number of lags, and $\mathrm{H}-\mathrm{L}$ stands for half-life. *Significant at $1 \%$ level.

Table 4: Consumer prices, growth rate

\begin{tabular}{cllcccc}
\hline Group & No. & $\boldsymbol{\Phi}$ & t-stat $(\boldsymbol{\Phi})$ & $\mathbf{k}$ & H-L & Standard error \\
\hline I & 15 & $0.976^{*}$ & -292.45 & 7 & 28.53 & 0.003 \\
II & 10 & $0.922^{*}$ & -122.99 & 7 & 8.54 & 0.007 \\
III & 4 & $0.949^{*}$ & -83.27 & 6 & 13.24 & 0.011 \\
\hline
\end{tabular}

Note: No. stands for the number of countries in a particular group, $\mathrm{k}$ denotes the number of lags, and $\mathrm{H}-\mathrm{L}$ stands for half-life. *Significant at $1 \%$ level.

\subsection{Money and Monetary Variables}

The convergence of growth in the money supply is the largest in the old EU15 Member States (e.g., $\Phi=0.874$ ), and the speed of convergence is represented by the smallest H-L (5.15). The results are a clear consequence of ECB monetary policy. After the new EU10 Member States had implemented monetary reforms (in some cases, they had also introduced new national currencies), the countries adopted tight exchange rate regimes. By pegging their currencies to the U.S. dollar, the Deutsche Mark, or to the Special Drawing Rights (basket), these countries actually gave up their independent monetary policy. Hence, high convergence (e.g., $\Phi=0.908$ and $\mathrm{H}-\mathrm{L}=7.18$ ) can be seen from this perspective. Several Balkan countries (including those of group III) hope to be considered for membership in a future round of EU expansion. Whether these countries can become serious candidates for membership will depend on their ability to align themselves with institutions and macroeconomic policies of the EU. Although structural change and institutional adaptation to the EU norms will be important in this process, the convergence of monetary policy between the EU and the candidate countries will be a necessary condition. In this context, the successful accession to the European Union will depend to a large extent on the ability of the candidate countries to achieve some measure of convergence between the evolution of the money supply and the monetary policy stance of the European Central Bank (ECB). On the other hand, weak policy coordination would suggest the need for strengthening the financial sectors of these countries, and for stabilizing their macroeconomic situation for a period in which they tie their policies more closely to the ECB before they can be considered serious candidates for EU membership. Figure 4 shows a dramatic increase in money supply in the 
Balkan countries. It led to an inflation surge that began in 1996, and it continued into 1997. The expanded money creation was used by these countries to cope with their economic difficulties. Our analysis confirmed the above need for strengthening the financial sectors of these countries by presenting high H-L (the number of the time periods that it takes to cut the gap in half) and the lowest degree of convergence (e.g., $\Phi=0.952$ ) in the segment of the M1 money growth rate.

\section{Table 5: The M1 money growth rate}

\begin{tabular}{ccccccc}
\hline Group & No. & $\boldsymbol{\Phi}$ & t-stat $(\boldsymbol{\Phi})$ & $\mathbf{k}$ & H-L & Standard error \\
\hline I & 15 & $0.874^{*}$ & -49.32 & 6 & 5.15 & 0.0178 \\
II & 10 & $0.908^{*}$ & -83.39 & 6 & 7.18 & 0.011 \\
III & 4 & $0.952^{*}$ & -82.44 & 6 & 14.09 & 0.011 \\
\hline
\end{tabular}

Note: No. stands for the number of countries in a particular group, $\mathrm{k}$ denotes the number of lags, and H-L stands for half-life. *Significant at $1 \%$ level.

\subsection{Interest Rates}

In the real interest rate spread (Table 7), the convergence is the greatest in the old EU15 Member States (e.g., $\Phi=0.865)$. Also, the convergence speed is represented by the smallest H-L (4.78), which indicates the number of the time periods that it takes to cut the gap in half. As in the case of the previous variable (e.g., M1 money stock), these results are a clear consequence of the ECB monetary policy. So, the old EU15 Member States represent the most homogenous group of countries in this analysed segment (e.g., the real interest rate spread). In the nominal interest rate spread (Table 6), coefficient $\Phi$ and the indicator H-L represent a completely different situation. While the lowest degree of convergence $(\Phi=0.980)$ can be found among all the groups of the analysed countries, H-L indicator also clearly shows the slowest pace of convergence $(\mathrm{H}-\mathrm{L}=34.31)$. This finding is consistent with the one of CPI convergence (see Table 4) where significant differences in inflation rates can be found in the group of the old EU15 Member States.

The greatest degree of convergence in the nominal interest spread can be found in the second group of the new EU10 Member States. The H-L indicator represents a high speed of convergence in this segment. Again, a clear correlation with the CPI growth rate can be found in Table 4, while the differences in the real interest rate still remain due to different country risk rates.

Based on our results for the third group of potential EU candidate countries, we are very cautious in drawing conclusions regarding the monetary policy convergence within the selected groups. The main reason for our caution is the nature of overall monetary policy that the countries adopted and implemented 
during the transition years. There are many conditions that the transition economies must meet if they are to achieve the convergence between themselves and the euro zone. Here are some of them: they must have the political will to do so, and their central banks must have the freedom to pursue appropriate policies. Also, financial markets must be developed enough to provide for effective transfer of central bank policies to business sector. In addition, they must choose an appropriate indicator to which they will seek to converge. The interest rates in these countries are unlikely to reflect EU levels, or cyclical fluctuations, even if the transition economies were to closely follow the ECB monetary policies. In part, this is due to the large differences in risk faced by depositors in transition economies and in the EU. Due to the existence of banks whose loan portfolios are non-performing, and because of the resulting risks and moral hazard problems as companies struggle to survive by accumulating debts that may never be repaid, risks in transition economies are much higher than they are in the EU. On the other hand, the return on capital may also be higher than it is in the EU due to the opportunities offered by restructuring economic activities. Finally, government policy strives to maintain a high spread between lending and deposit rates in order to help the banking system to deal with the losses from problem loans.

\section{Table 6: The nominal interest rate spread}

\begin{tabular}{ccccccc}
\hline Group & No. & $\Phi$ & t-stat $(\Phi)$ & $\mathrm{k}$ & $\mathrm{H}-\mathrm{L}$ & Standard error \\
\hline I & 15 & $0.980^{*}$ & -212.274 & 6 & 34.31 & 0.005 \\
II & 10 & $0.911^{*}$ & -82.38 & 7 & 7.44 & 0.011 \\
III & 4 & $0.939^{*}$ & -43.44 & 6 & 11.01 & 0.022 \\
\hline
\end{tabular}

Note: No. stands for the number of countries in a particular group, k denotes the number of lags, and $\mathrm{H}-\mathrm{L}$ stands for half-life. *Significant at $1 \%$ level.

\section{Table 7: The real interest rate spread}

\begin{tabular}{ccccccc}
\hline Group & No. & $\Phi$ & t-stat $(\Phi)$ & $\mathrm{k}$ & H-L & Standard error \\
\hline I & 15 & $0.865^{*}$ & -90.31 & 7 & 4.78 & 0.009 \\
II & 10 & $0.904^{*}$ & -100.52 & 7 & 6.87 & 0.009 \\
III & 4 & $0.938^{*}$ & -65.07 & 4 & 10.83 & 0.014 \\
\hline
\end{tabular}

Note: No. stands for the number of countries in a particular group, k denotes the number of lags, and H-L stands for half-life. *Significant at $1 \%$ level.

\section{$5 \quad$ Conclusion}

At the beginning of the decade, the need to manage the forthcoming enlargement of the European Union in the eastern regions to prevent a further deepening of the regional socio-economic division between the future EU members and the nonmembers living next to each other made continuing policies towards the CEE countries more open for both potential new members from the CEE region and the 
EU. The literature that addresses the consequences of greater economic openness, trade liberalisation, increased economic integration, and closer links with more advanced regions largely supports conventional assumptions about the positive benefits that countries should expect. Based primarily on the Heckscher-Ohlin (HO) model of international trade, forecasts about the benefits are of two kinds. Firstly, economic integration improves competitiveness; it promotes economic growth and reduces prices; it also increases aggregate welfare. Secondly, integration promotes convergence in the cost of production factors (labour, capital, and land), and ultimately in the standard of living. For the less and more advanced economies, economic integration benefits are thought to be greater than losses. Through economic integration, economies should grow more rapidly. There should be an overall increase in the standard of living, and less-skilled labour in the less-advanced countries should benefit from rising wages. EU membership is seen as the logical completion of the economic integration process. If trade liberalisation implies a greater capability for economic competitiveness and growth, then EU membership should generate the greatest possible return on the political decision to integrate. The opening of the new border crossings, primarily on the state borders with the old EU Member States, should be treated as a significant factor stimulating regional and local development.

One of the aims of this paper is to confirm the hypothesis that linking the economies of Central and Eastern Europe (the new EU10 Member States) to those of the European Union (EU) is generally considered the principal means of securing the future growth prospects and political stability of the new Member States. We show that common institutional features and economic policies tend to correlate with a higher degree of convergence. After testing for convergence, we found evidence of convergence in macroeconomic fundamentals in all the three country groups. However, the strength of the results differs for particular variables as well as for country groups. Regarding the macroeconomic variables, the highest degree of convergence is achieved in growth rates of real output in all groups of economies. The growth rates of producer and consumer prices converge at the slowest pace. However, these rates tend to converge towards the low inflation region in most countries. For the Central and Eastern European countries, the membership in the European Union is seen as the key to political and economic stability, and ultimately to prosperity. The 'return to Europe' is expected to bring rewards exceeding the costs of EU accession, and the governments of Central and Eastern Europe have adopted market reforms and EU regulations with a passion. There is a broad consensus that closer economic ties with the EU represent the most promising alternative for the future prospects of the new EU10 Member States. As regards the CEE countries, the reasons for establishing large-scale regional and local cooperation are: (1) historical reasons derived from the fact that the development of these areas is the result of the common cultural heritage; (2) political reasons where cross-border cooperation is a significant factor for stabilising and directing development; (3) economic reasons for promoting economic activities in border regions, and (4) social reasons - aiming at 
establishing social contacts, breaking barriers and prejudices, better understanding, building bridges between inhabitants of neighbouring regions. We carried out a quantitative analysis to test for convergence in selected macroeconomic variables within specific groups of the CEE countries from January 1993 to December 2003. The logical formation of groups of transition countries reflects the institutional attributes of the transition process. A certain degree of macroeconomic convergence has been achieved in the new EU10 Member States despite diverse starting conditions at the beginning of transformation, different institutional features accompanying transition, and distinct privatisation techniques adopted. Comparing convergence across groups of countries, the new EU10 Member States have achieved the highest degree of convergence in basic macroeconomic fundamentals. The high degree of convergence, specifically in the growth rates of PPI and money, as well as in interest rate spreads, i.e., the monetary variables can be observed in the second group. We attribute convergence to two important factors. First, the international trade within the framework of EU enlargement serves as a natural means of coordinating economic development. Second, the prospective accession to the EU serves as an institutional means of coordination in order to satisfy a set of preaccession criteria.

For the third group of countries, a highly aggregated approach of this paper represents a shortcoming. The process and the dynamics of economic reform depend strongly on the specific economic structure present in individual countries. In the applicant countries of the third group, substantial progress has been made in several areas, e.g., with respect to the liberalisation of prices (for installing the market price system in the first place) with regard to the established foreign exchange markets, or with regard to trade. In other areas, further efforts are required. Examples include privatisation and banking sector reform. However, the $\mathrm{EU}$ is the explicit destination of these countries' development journey. Individual countries vary substantially in the projected convergence time. In our quantitative experiments, integration effects and potential accession to the EU are significantly positive. Substantial acceleration of convergence times may be possible. A more detailed analysis with sectoral disaggregation is required to obtain a further understanding of the convergence process in applicant countries in the future. Sectoral disaggregation is especially interesting when studying transition economies because a substantial degree of sectoral reallocation is observed throughout the transition process. It not only influences the allocation of the foreign direct investments undertaken in new places, but it also influences the efficiency of the local economic sector. A new private sector is emerging, the state sector is declining, and the agricultural sector is oversized in some countries. We see our contribution not as a substitute for a detailed investigation into the mechanics of sectoral adjustment, but more as a complement that is intended to give a bird-eye's view. The second dimension where further disaggregation can be expected to shed further light on the growth prospects is regional disaggregation. 
In some of the Balkan countries, it is observed that growth is based on a relatively small set of regions and sectors. Further ongoing work should be devoted to assessing the extent and the implications of a possibly observable Harrod-BalassaSamuelson effect in the Balkan countries. The fast-rising prices in fast-growing countries may speed up (nominal) convergence towards the EU. In final conclusion, one may say that convergence of applicant countries towards the EU level is a long-run perspective. This perspective can be and is influenced by domestic policy choices in the applicant countries, and by the EU policy approach towards enlargement and candidate countries.

\section{Notes}

${ }^{1}$ Cyprus, Czech Republic, Estonia, Latvia, Lithuania, Hungary, Malta, Poland, Slovakia, and Slovenia

${ }^{2}$ See the European Commission's White Paper on the "Preparation of the Associated Countries of Central and Eastern Europe for Integration in the Internal Market of the European Union" (European Commission, 1995).

${ }^{3}$ See also Evans and Karras, 1996; Evans, 1998; Fleissig and Strauss, 2001 and Kočenda, 2001

\section{References}

Baldwin, R. E. \& Seghezza E. (1996) Growth and European Integration: Towards and Empirical Assessment, CEPR Discussion Paper No. 1393 (Washington D.C.: CEPR).

Barro, R.J. (1991) Economic Growth in Cross-Section of Countries, Quarterly Journal of Economics, 106(2), pp. 407-443, doi: 10.2307/2937943.

Barro, R. J. \& Sala-i-Martin, X. (1992) Convergence Across States and Regions, Brookings Papers on Economic Activity, 1, pp.107-158.

Barro, R. J. \& Sala-i-Martin, X. (1992) Convergence, Journal of Political Economy, 100(2), pp. 223-251.

Baumol, W. J. (1986) Productivity Growth, Convergence, and Welfare: What the LongRun Data Show, American Economic Review, 76(5), pp. 1072-1085.

Ben-David, D. (1993) Equalizing Exchange: Trade Liberalization and Income Convergence, Quarterly Journal of Economics, 108(3), pp. 653-679, doi: $10.2307 / 2118404$.

Ben-David, D. (1995) Measuring Income Convergence: An Alternative Test, Working Paper No. 41/95 (Tel Aviv: University of Tel Aviv).

Ben-David, D. (1996) Trade Convergence Among Countries, Journal of International Economics, 40(3-4), pp. 279-298, doi: 10.1016/0022-1996(95)01405-5.

Bernard, A. B. \& Durlauf S. N. (1996) Interpreting Tests of Convergence Hypothesis, Journal of Econometrics, 71(1-2), pp. 161-173, doi: 10.1016/0304-4076(94)01699-2.

Bernard, A. B. \& Durlauf, S. N. (1995) Convergence in International Output, Journal of Applied Econometrics, 10(2), pp. 97-108, doi: 10.1002/jae.3950100202.

Boldrin, M. \& Canova, F. (2003) Regional Policies and EU Enlargement, CEPR Discussion Paper No. 3744 (London: CEPR).

Brada, J. C. \& Kutan, A. M. (2001) The Convergence of Monetary Policy between Candidate Countries and the European Union, Economic Systems, 25(3), pp. 215-231, doi:10.1016/S0939-3625(01)00027-9. 
Brada, J. C., Kutan, A. M. \& Zhou, S. (2003) Real and Monetary Convergence between the European Union and Transition-Economy Candidate Countries: Market Integration and Policy Coordination, Journal of Banking and Finance, 29, pp. 249-270.

Campbell, J. Y. \& Perron, P. (1991) Pitfalls and Opportunities: What Macroeconomists Should Know About Unit Roots, In: Blanchard, O. J. \& Fischer, S. (eds) NBER Macroeconomics Annual, 6, pp. 141-201 (Cambridge, MA/London: MIT Press).

Crespo-Cuaresma, J., Ritzberger-Grünwald, D., \& Silgoner, M. A. (2002) Growth, Convergence and EU Membership, Working Paper, No. 62 (Vienna: National Bank of Austria).

Čihák, M. \& Holub, T. (2001) Convergence of Relative Prices and Inflation in Central and Eastern Europe, IMF Working Paper No. 01/124 (Washington D.C: IMF).

Čihák, M. \& Holub, T. (2003) Price Convergence to the EU: What do the 1999 ICP Data Tell Us? The Czech National Bank Working Paper No. 2/2003 (Prague: Czech National Bank).

Dickey, D. A. \& Fuller, W. A. (1979) Distribution of the Estimators for Autoregressive Time Series with a Unit Root, Journal of the American Statistical Association, 74(366), Part 1, pp. 427-431.

Dollar, D. (1992) Outward Oriented Developing Economies Really Do Grow More Rapidly: Evidence from 95 LDCs, 1976-1985, Economic Development and Cultural Change, 40(3), pp. 523-544.

Dowrick, S. \& Nguyen D. (1989) OECD Comparative Economic Growth 1950-85: CatchUp and Convergence, American Economic Review, 79(5), pp. 1010-30.

Doyle, P., Kuijs, L. \& Jiang G. (2001) Real Convergence to EU Income Levels: Central Europe from 1990 to the Long Term, IMF Working Paper, No. 01/146 (Washington D.C.: IMF).

Égert, B. (2002) Investigating the Balassa-Samuelson Hypothesis in Transition: Do We Understand What We See? A Panel Study, Economics of Transition, 10(2), pp. 273309, doi: 10.1111/1468-0351.00112.

Eichengreen, B. \& Kohl, R. (1998) The External Sector, the State, and Development in Eastern Europe, BRIE Working Paper No. 125 (Berkeley: University of California).

Estrin, S., Urga, G. \& Lazarova, S. (2001) Testing for Ongoing Convergence in Transition Economies, 1970 to 1998, Journal of Comparative Economics, 29(4), pp. 677-691, doi:10.1006/jcec.2001.1736.

Evans, P. \& Karras, G. (1996) Convergence Revisited, Journal of Monetary Economics, 37(2), pp. 249-65, doi: 10.1016/S0304-3932(96)90036-7.

Evans, P. (1998) Using Panel Data to Evaluate Growth Theories, International Economic Review, 39(2), pp. 295-306.

Fleissig, A. \& Strauss, J. (2001) Panel Unit-Root Tests of OECD Stochastic Convergence, Review of International Economics, 9(1), pp. 153-62, doi: 10.1111/1467-9396.00270.

Giavazzi, F. \& Giovannini, A. (1989) Limited Exchange Rate Flexibility: The European Monetary System (Cambridge, MA/London: MIT Press).

Grossman, G. M. \& Helpman E. (1991) Innovation and Growth in the Global Economy (Cambridge: MIT Press).

Henrekson, M., Thorstensson J. \& Thorstensson R. (1997) Growth Effects of European Integration, European Economic Review, 41(8), pp. 1537-57, doi: 10.1016/S00142921(97)00063-9.

Im, K. S., Pesaran, M. H \& Shin, Y. (2003) Testing for Unit Roots in Heterogeneous Panels, Journal of Econometrics, 115(1), pp. 53-74, doi: 10.1016/S03044076(03)00092-7. 
Islam, N. (1995) Growth Empirics: A Panel Data Approach, Quarterly Journal of Economics, 110(4), pp.1127-70, doi: 10.2307/2946651.

Janáčková, S. (2000) Price Convergence and the Readiness of the Czech Economy for Accession to the European Union, Eastern European Economics, 38(4), pp. 73-91.

Jongen L. W. (2004) An analysis of past and future GDP growth in Slovenia, Working paper, No. 25 (Ljubljana: Institute for Economic Research).

Judson, R. A. \& Owen A. L. (1999) Estimating Dynamic Panel Data Models: a Guide for Macroeconomists, Economics Letters, 65(1), pp. 9-15, doi: 10.1016/S01651765(99)00130-5.

Kaminski, B. \& Riboud M. (2000) Foreign Investment and Restructuring: The Evidence from Hungary, Technical Paper No. 453 (Washington D.C.: World Bank).

Kaminsky, G., Lizondo, S. \& Reinhart, C. M. (1997) Leading Indicators of Currency Crises, International Monetary Fund Working Paper No. 97/79 (Washington D.C.: IMF).

Kočenda, E. (2001) Macroeconomic Convergence in Transition Economies, Journal of Comparative Economics, 29(1), pp.1-23, doi: 10.1006/jcec.2000.1696.

Kočenda, E. \& Papell, D. (1997) Inflation Convergence within the European Union: A Panel Data Analysis, International Journal of Finance \& Economics, 2(3), pp. 189198, doi:10.1002/(SICI)1099-1158(199707)2:3<189::AID-IJFE46>3.0.CO;2-6.

Kočenda, E. \& Hanousek, J. (1998) Integration of Emerging Equity Markets: Major Asian Players, Korean Economic Review, 14(1), pp. 99-114.

Korez V. R., Bobek, V., Cancer, V., Perko, I. \& Hauptman, L. (2010) The efficiency of entrepreneurship policy support for the internationalisation of SMEs: The case of Slovenia, European Journal of International Management, 4(6), pp. 644-664, doi:10.1504/EJIM.2010.035593.

Krugman, P. \& Obstfeld, M. (1994) International Economics: Theory and Policy, third edition (NYC: Harper Collins College Publishers).

Kutan, A. M. \& Yigit T. M. (2004) Nominal and Real Stochastic Convergence within the Transition Economies: Panel Evidence, Journal of Comparative Economics, 32 (1), pp. 23-36, doi:10.1016/j.jce.2003.09.008.

Lee, K., Pesaran M. H. \& Smith R. (1997) Growth and Convergence in Multi-country Empirical Stochastic Solow Model, Journal of Applied Econometrics, 12(4), pp. 35792, doi:10.1002/(SICI)1099-1255(199707)12:4<357::AID-JAE441>3.0.CO;2-T.

Levin, A. \& Lin, C. (1992) Unit Root Tests in Panel Data: Asymptotic and Finite-Sample Properties, Discussion Paper No. 92-23 (San Diego: University of California).

Lucas, R.E. (1998). On the Mechanics of Economic Development, Journal of Monetary Economics, 22(1), pp. 3-42, doi: 10.1016/0304-3932(88)90168-7.

Martin, C. \& Velázquez, F. J. (2001) An Assessment of Real Convergence of Less Developed EU Members: Lessons for the CEEC Candidates, Working Paper No. 5/2001 (European Economy Group).

Nerlove, M. (2000) Growth Rate Convergence, Fact or Artifact? An Essay on Panel Data Econometrics, In: Balestra, P., Ronchetti, E. \& Krishnakumar, J. (eds) Panel data econometrics: Future directions: Papers in honour of Professor Pietro Balestra (Amsterdam: Elsevier Science Ltd.).

Ng, S. \& Perron, P. (1995) Unit Root Tests in ARMA Models with Data-Dependent Methods for the Selection of the Truncation Lag, Journal of the American Statistical Association, 90(429), pp. 268-281.

Ovin, R. \& Maček, A. (2010) How beneficial are inward C-B M \& A for European countries?, European Journal of International Management, 4(5), pp. 488-505, doi: 10.1504/EJIM.2010.034963. 
Quah, D. (1992) International Patterns of Growth: Persistence in Cross-Country Disparities Working Paper (London: London School of Economics).

Richards, A. J. \& Tersman G. H. R. (1996) Growth, Nontradables, and Price Convergence in the Baltics, Journal of Comparative Economics, 23(2), pp. 121-145, doi: 10.1006/jcec.1996.0051.

Rivera-Batiz, R. A. \& Romer, P. M. (1991) Economic Integration and Growth, Quarterly Journal of Economics, 106(2), pp. 531-55, doi: 10.2307/2937946.

Sachs, J. D. \& Warner, A. M. (1996) Achieving Rapid Growth in the Transition Economies of Central Europe, Working Paper No. 116, (Stockholm: Stockholm Institute of East European Economies).

Sachs, J. D. \& Warner, A. (1995) Economic Convergence and Economic Policies, Discussion Paper No. 502 (Boston: Harvard University).

Sarno, L. (1997) Policy Convergence, the Exchange Rate Mechanism and the Misalignment of Exchange Rates: Some Tests of Purchasing Power Parity and Generalized Purchasing Power Parity, Applied Economics, 29(5), pp. 591-605, doi: 10.1080/000368497326796.

Sen, A. (2003) On Unit-Root Tests When the Alternative Is a Trend-Break Stationary Process, Journal of Business \& Economics Statistics, 21(1), pp. 174-184, doi:10.1198/073500102288618874.

Senjur, M. (2007) A Development Club and Groupings in Europe, and Growth Strategies, Comparative Economic Studies, 49(4) pp.660-682, doi: 10.1057/palgrave.ces.8100222.

Solow, R. (1956) A Contribution to the Theory of Economic Growth, Quarterly Journal of Economics, 70(1), pp. 65-94, doi: 10.2307/1884513.

Svetličič, M., Jaklič, A. \& Burger, A. (2007) Internationalization of Small and MediumSized Enterprises from Selected Central European Economies, Eastern European Economics, 45(4), pp. 37-66.

Vojinović, B. \& Oplotnik, Ž. J. (2008) Real convergence in the new EU Member States, Prague Economic Papers, 1, pp. 23-39.

Vojinović, B., Oplotnik, Ž. J. \& Próchniak, M. (2010) EU enlargement and real economic convergence, Post-Communist Economies, 22(3), pp. 303-322, doi: 10.1080/14631377.2010.498681.

Wagner, M. \& Hlouskova, J. (2002) The CEEC10's Real Convergence Prospects, CEPR Discussion Paper No. 3318 (Washington D.C.: CEPR).

Zysman, J. \& Schwartz, A. (1998) Reunifying Europe in an Emerging World Economy: Economic Heterogeneity, new Industrial Options, and Political Choices, Journal of Common Market Studies, 36(3), pp. 405-429, doi: 10.1111/1468-5965.00117. 


\section{Appendices}

Table 8: Averages, standard deviations and variation coefficients

\begin{tabular}{|c|c|c|c|c|c|c|c|c|c|}
\hline & \multicolumn{3}{|c|}{$\begin{array}{l}\text { Industrial production } \\
\text { growth rate }\end{array}$} & \multicolumn{3}{|c|}{$\begin{array}{l}\text { Producer prices growth } \\
\text { rate }\end{array}$} & \multicolumn{3}{|c|}{$\begin{array}{l}\text { Consumer prices } \\
\text { growth rate }\end{array}$} \\
\hline & 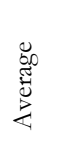 & 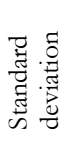 & 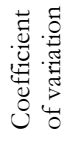 & 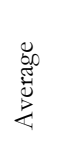 & 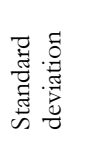 & 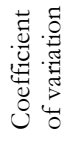 & 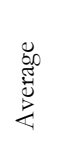 & 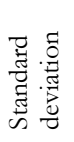 & 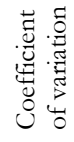 \\
\hline \multicolumn{10}{|l|}{ Group I } \\
\hline Average & 0.81 & 6.07 & 7.49 & 1.66 & 3.09 & 1.86 & 2.93 & 2.42 & 0.82 \\
\hline Austria & 2.71 & 3.74 & 1.38 & 0.58 & 1.75 & 3.02 & 2.20 & 1.05 & 0.48 \\
\hline Belgium & 0.21 & 3.73 & 17.64 & 1.08 & 3.76 & 3.49 & 2.00 & 0.74 & 0.37 \\
\hline Denmark & 1.25 & 6.74 & 5.40 & 1.10 & 2.00 & 1.82 & 2.15 & 0.47 & 0.22 \\
\hline Finland & 3.45 & 5.93 & 1.72 & 0.67 & 3.06 & 4.57 & 1.80 & 1.11 & 0.62 \\
\hline France & -0.69 & 1.23 & -1.78 & 1.55 & 1.94 & 1.26 & 1.74 & 0.72 & 0.41 \\
\hline Germany & -1.16 & 3.74 & -3.23 & 0.85 & 1.63 & 1.92 & 2.03 & 1.35 & 0.67 \\
\hline Greece & -5.24 & 6.94 & -1.32 & 6.28 & 4.32 & 0.69 & 7.62 & 4.96 & 0.65 \\
\hline Ireland & 9.60 & 7.66 & 0.80 & 1.23 & 3.05 & 2.48 & 3.70 & 1.52 & 0.41 \\
\hline Italy & -1.61 & 3.11 & -1.93 & 2.48 & 2.51 & 1.01 & 3.41 & 1.41 & 0.41 \\
\hline Luxembourg & 2.04 & 6.68 & 3.28 & 0.19 & 3.16 & 17.04 & 2.18 & 0.91 & 0.42 \\
\hline $\begin{array}{l}\text { The } \\
\text { Netherlands }\end{array}$ & -0.59 & 3.29 & -5.59 & 1.60 & 1.61 & 1.01 & 2.70 & 0.83 & 0.31 \\
\hline Portugal & -0.45 & 3.06 & -6.81 & 1.29 & 1.58 & 1.23 & 4.49 & 2.52 & 0.56 \\
\hline Spain & -0.51 & 4.47 & -8.83 & 2.10 & 2.10 & 1.00 & 3.66 & 1.32 & 0.36 \\
\hline $\mathrm{UK}$ & -1.28 & 2.89 & -2.26 & 1.94 & 1.76 & 0.91 & 2.33 & 1.74 & 0.75 \\
\hline Sweden & 2.27 & 5.13 & 2.26 & 1.59 & 3.45 & 2.17 & 2.31 & 2.52 & 1.09 \\
\hline \multicolumn{10}{|l|}{ GroupII } \\
\hline Average & -4.49 & 14.09 & -3.14 & 6.56 & 11.37 & 1.73 & 12.05 & 19.07 & 1.58 \\
\hline Cyprus & -1.55 & 6.38 & -4.10 & 2.77 & 2.10 & 0.76 & 3.56 & 1.57 & 0.44 \\
\hline Czech & 0.21 & 6.40 & 30.13 & 3.04 & 2.56 & 0.84 & 5.76 & 3.68 & 0.64 \\
\hline Estonia & -1.15 & 8.72 & -7.55 & 6.39 & 7.65 & 1.20 & 17.77 & 24.88 & 1.40 \\
\hline Hungary & -7.75 & 15.81 & -2.04 & 12.22 & 8.97 & 0.73 & 15.49 & 7.62 & 0.49 \\
\hline Latvia & -2.41 & 9.26 & -3.85 & 3.65 & 5.22 & 1.43 & 15.18 & 23.28 & 1.53 \\
\hline Lithuania & -1.96 & 23.11 & -11.78 & 5.47 & 12.07 & 2.21 & 22.40 & 42.45 & 1.90 \\
\hline Malta & & & & & & & 2.62 & 1.34 & 0.51 \\
\hline Poland & -12.98 & 19.92 & -1.54 & 14.76 & 12.20 & 0.83 & 19.11 & 16.10 & 0.84 \\
\hline Slovakia & -1.08 & 4.90 & -4.53 & 5.93 & 3.25 & 0.55 & 8.01 & 3.21 & 0.40 \\
\hline Slovenia & -6.35 & 9.38 & -1.48 & 1.96 & 22.08 & 11.27 & 11.35 & 8.77 & 0.77 \\
\hline \multicolumn{10}{|l|}{ Group III } \\
\hline Average & -15.08 & 27.33 & -1.81 & 55.84 & 86.64 & 1.55 & 35.92 & 49.68 & 1.38 \\
\hline Bulgaria & 3.71 & 6.12 & 1.65 & 45.77 & 82.87 & 1.81 & 50.93 & 70.21 & 1.38 \\
\hline Croatia & 1.77 & 6.18 & 3.48 & 58.67 & 120.17 & 2.05 & 3.87 & 1.73 & 0.45 \\
\hline Romania & -37.87 & 27.65 & -0.73 & 59.43 & 38.91 & 0.65 & 57.26 & 39.55 & 0.69 \\
\hline Albania & 0.00 & 0.00 & 0.00 & 0.00 & 0.00 & 0.00 & 23.53 & 34.86 & 1.48 \\
\hline
\end{tabular}

Note: Data sets were compiled from the International Monetary Fund's WEO - World Economic Indicators 

and EU Integration Process

Table 9: Averages, standard deviations and correlation coefficients

\begin{tabular}{|c|c|c|c|c|c|c|c|c|c|}
\hline & \multicolumn{3}{|c|}{$\begin{array}{l}\text { Money aggregate } \\
\text { (M1) growth rate }\end{array}$} & \multicolumn{3}{|c|}{$\begin{array}{c}\text { Interest spread real } \\
\text { growth rate }\end{array}$} & \multicolumn{3}{|c|}{$\begin{array}{c}\text { Interest spread } \\
\text { nominal growth rate }\end{array}$} \\
\hline & 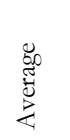 & 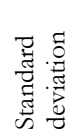 & 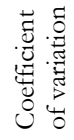 & 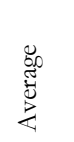 & 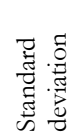 & 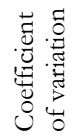 & 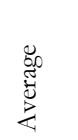 & 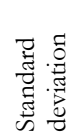 & 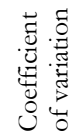 \\
\hline \multicolumn{10}{|l|}{ Group I } \\
\hline Average & 5.16 & 5.04 & 0.98 & 3.71 & 0.41 & 0.11 & -1.11 & 3.46 & -3.12 \\
\hline Austria & 7.86 & 2.75 & 0.35 & -0.41 & 2.93 & -7.22 & 2.41 & 3.33 & 1.38 \\
\hline Belgium & 1.52 & 14.96 & 9.86 & 4.78 & 0.72 & 0.15 & -2.88 & 0.81 & -0.28 \\
\hline Denmark & 5.32 & 4.86 & 0.91 & 4.99 & 0.03 & 0.01 & 1.76 & 1.29 & 0.73 \\
\hline Finland & 2.93 & 4.12 & 1.40 & 4.10 & 0.73 & 0.18 & -2.32 & 1.20 & -0.52 \\
\hline France & 2.95 & 3.49 & 1.18 & 3.78 & 0.73 & 0.19 & -2.16 & 0.71 & -0.33 \\
\hline Germany & 7.58 & 2.55 & 0.34 & 6.60 & 0.53 & 0.08 & -4.30 & 1.97 & -0.46 \\
\hline Greece & 6.09 & 11.85 & 1.95 & 7.06 & 1.68 & 0.24 & -0.29 & 3.16 & -10.97 \\
\hline Ireland & -2.10 & 17.27 & -8.21 & 5.29 & 1.84 & 0.35 & -0.47 & 1.65 & -3.54 \\
\hline Italy & 5.55 & 3.89 & 0.70 & 5.16 & 1.20 & 0.23 & -1.97 & 0.84 & -0.43 \\
\hline Luxembourg & 6.35 & 4.28 & 0.67 & 1.83 & 1.05 & 0.57 & 0.98 & 1.44 & 1.47 \\
\hline $\begin{array}{l}\text { The } \\
\text { Netherlands }\end{array}$ & 5.48 & 20.51 & 3.74 & 3.16 & 2.58 & 0.82 & -0.56 & 2.61 & -4.65 \\
\hline Portugal & 11.27 & 3.55 & 0.32 & 4.94 & 1.41 & 0.29 & 0.61 & 2.58 & 4.25 \\
\hline Spain & 6.20 & 4.88 & 0.79 & 2.40 & 0.74 & 0.31 & 1.25 & 1.17 & 0.93 \\
\hline Sweden & 0.91 & 71.29 & 78.04 & -1.64 & 1.37 & -0.84 & -6.53 & 47.46 & -7.27 \\
\hline $\mathrm{UK}$ & 6.12 & 1.76 & 0.29 & 3.40 & 1.36 & 0.40 & -1.48 & 2.16 & -1.46 \\
\hline \multicolumn{10}{|l|}{ GroupII } \\
\hline Average & 16.61 & 7.93 & 0.48 & 6.12 & 2.52 & 0.41 & -6.71 & 10.68 & -1.59 \\
\hline Cyprus & 8.13 & 9.23 & 1.14 & 2.31 & 0.79 & 0.34 & 1.14 & 1.33 & 1.17 \\
\hline Czech & 14.52 & 16.85 & 1.16 & 5.14 & 0.98 & 0.19 & -0.85 & 3.20 & -3.75 \\
\hline Estonia & 25.21 & 23.33 & 0.93 & 8.51 & 6.92 & 0.81 & -10.12 & 20.18 & -1.99 \\
\hline Hungary & 15.26 & 5.12 & 0.34 & 5.31 & 2.60 & 0.49 & -9.16 & 5.01 & -0.55 \\
\hline Latvia & 15.74 & 11.45 & 0.73 & 12.12 & 10.28 & 0.85 & -3.71 & 23.51 & -6.34 \\
\hline Lithuania & 21.80 & 20.29 & 0.93 & 7.20 & 5.27 & 0.73 & -15.67 & 43.67 & -2.79 \\
\hline Malta & 4.99 & 5.15 & 1.03 & 3.07 & 0.79 & 0.26 & -0.38 & 1.37 & -3.62 \\
\hline Poland & 20.40 & 10.20 & 0.50 & 4.46 & 2.82 & 0.63 & -11.93 & 14.10 & -1.18 \\
\hline Slovakia & 9.70 & 11.02 & 1.14 & 5.37 & 1.64 & 0.30 & -2.74 & 2.91 & -1.06 \\
\hline Slovenia & 25.91 & 16.13 & 0.62 & 7.83 & 4.36 & 0.56 & -4.00 & 5.51 & -1.38 \\
\hline \multicolumn{10}{|l|}{ Group III } \\
\hline Average & 34.36 & 21.66 & 0.63 & 7.45 & 9.42 & 1.26 & -32.64 & 36.00 & -1.10 \\
\hline Albania & 14.51 & 18.26 & 1.26 & 4.16 & 10.04 & 2.41 & -19.68 & 38.26 & -1.94 \\
\hline Bulgaria & 52.12 & 62.14 & 1.19 & 17.44 & 17.55 & 1.01 & -33.93 & 62.00 & -1.83 \\
\hline Croatia & 19.82 & 13.86 & 0.70 & 11.12 & 3.28 & 0.29 & 7.24 & 3.82 & 0.53 \\
\hline
\end{tabular}

Note: Data sets were compiled from the International Monetary Fund's WEO - World Economic Indicators 


\section{Figure 1: Real industrial output growth rate}

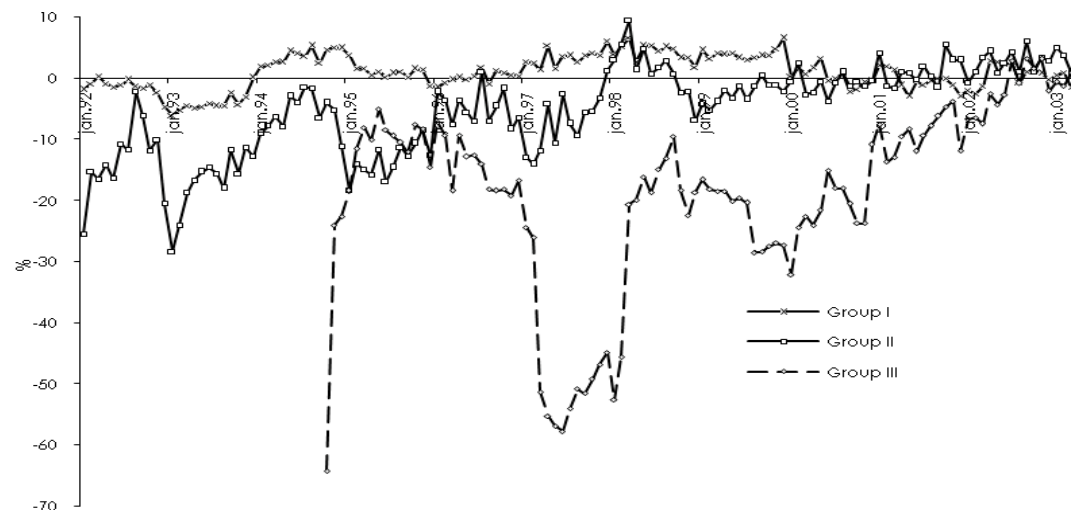

Note: data sets were compiled from the International Monetyr Fund's WEO - World Economic Indicators

Figure 2: $\quad$ Producer prices growth rate.

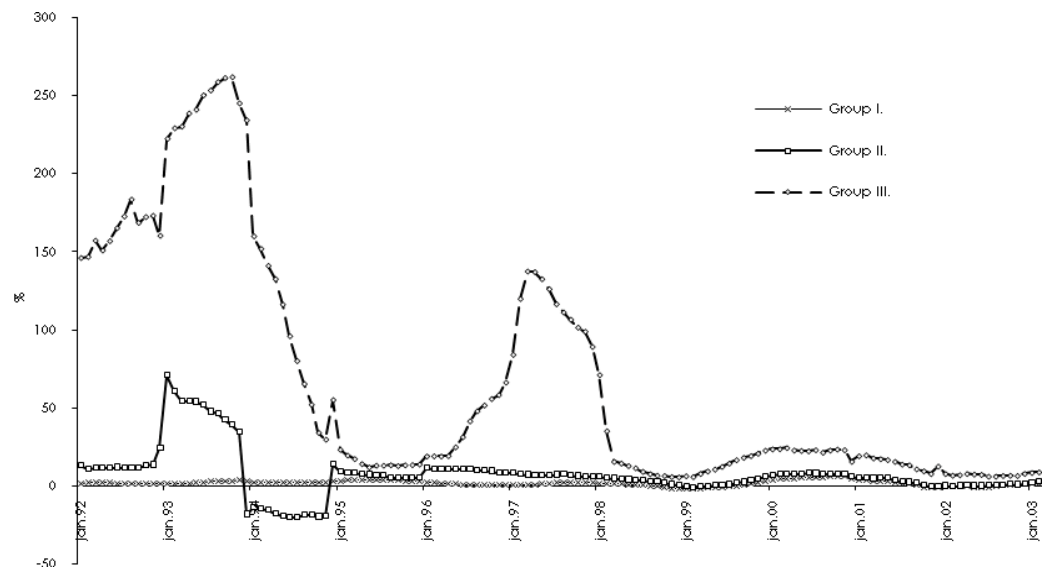

Note: Data sets were compiled from the International Monetary Fund's WEO - World Economic Indicators 


\section{Figure 3: Consumer prices growth rate.}

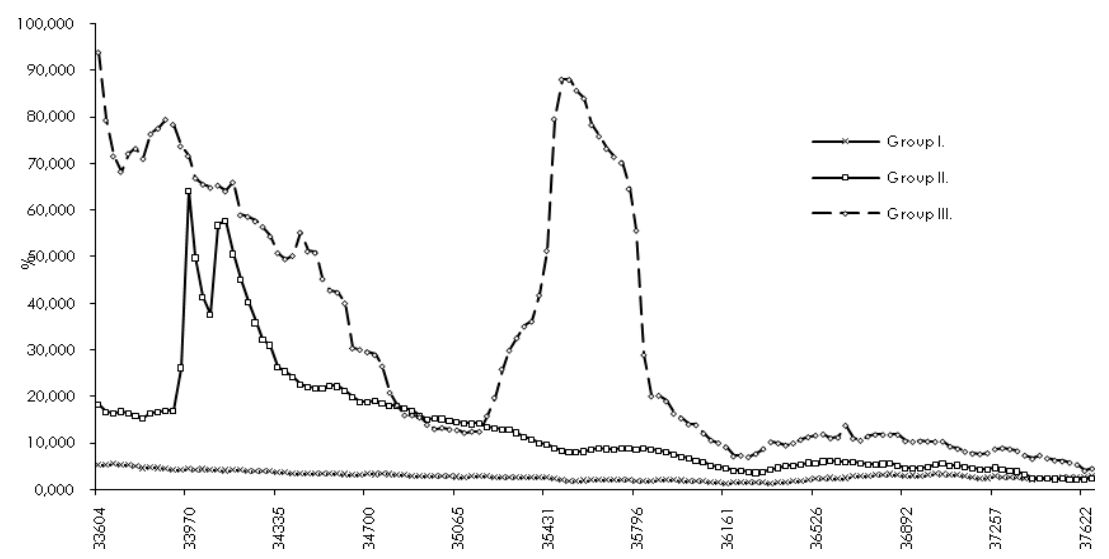

Note: Data sets were compiled from the International Monetary Fund's WEO - World Economic Indicators

Figure 4: Money (M1) growth rate.

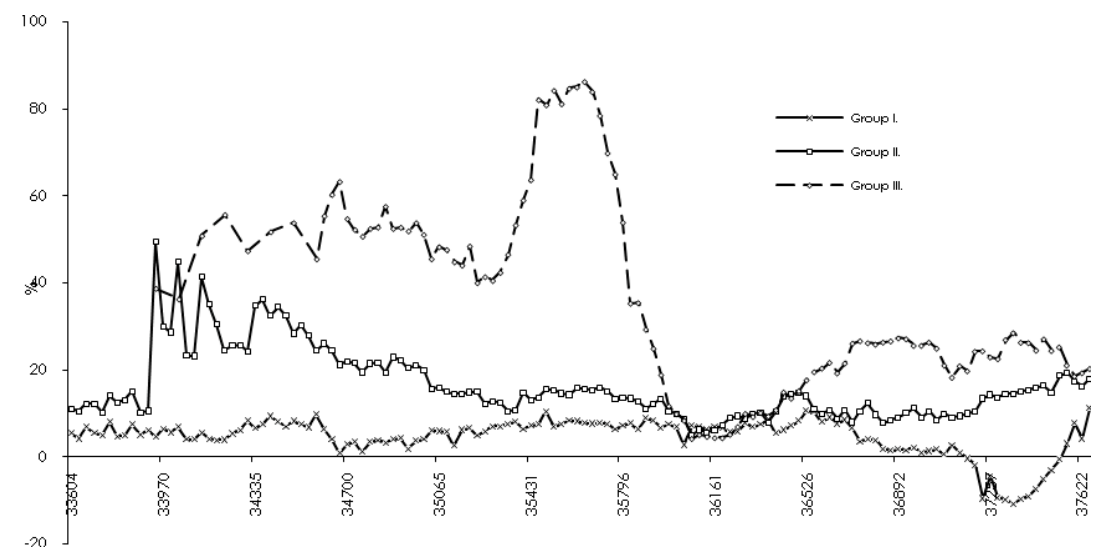

Note: Data sets were compiled from the International Monetary Fund's WEO - World Economic Indicators. 


\section{Figure 5: Nominal interest rate spreads.}

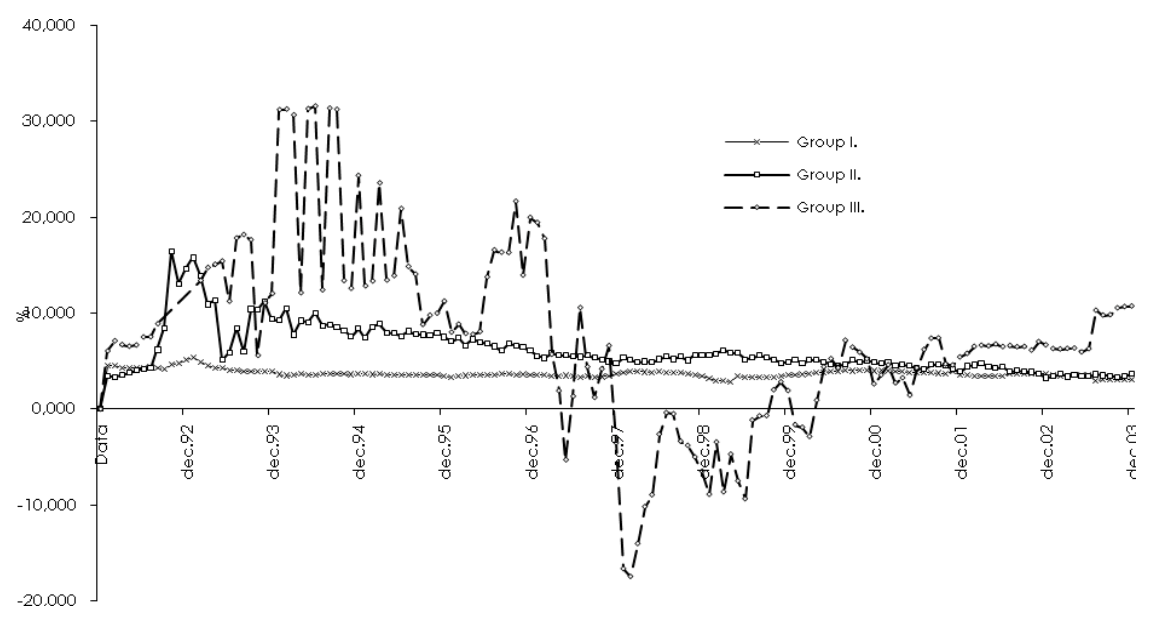

Note: Data sets were compiled from the International Monetary Fund's WEO - World Economic Indicators.

Figure 6: Real interest rate spreads.

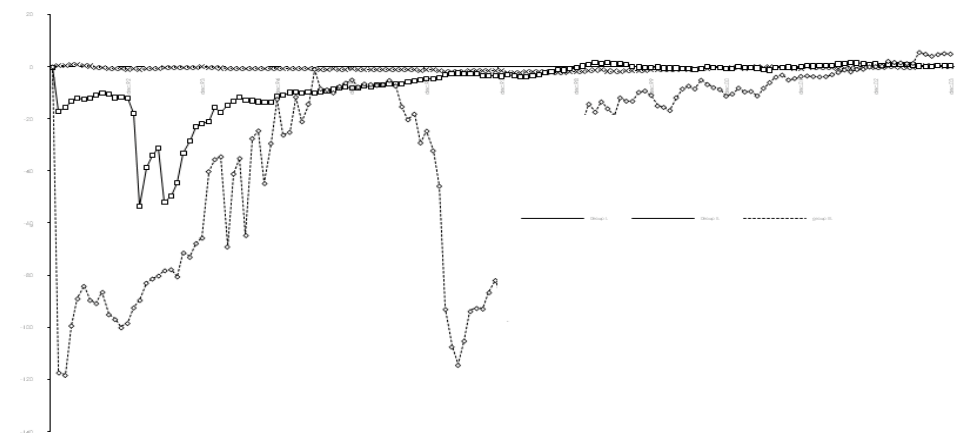

Note: Data sets were compiled from the International Monetary Fund's WEO - World Economic Indicators 